\title{
ANALISIS MODEL-MODEL PEMBELAJARAN YANG DIGUNAKAN OLEH GURU IPS DI SMP NEGERI SE-KECAMATAN SUKOREJO KABUPATEN KENDAL
}

\author{
Panggih Nugroho Wicaksono, Arif Purnomo ${ }^{\bowtie}$ \\ Prodi Pendidikan Ilmu Pengetahuan Sosial, Fakultas Ilmu Sosial, Universitas Negeri Semarang, Indonesia
}

\section{Info Artikel}

Sejarah Artikel:

Disubmit: Januari 2021

Direvisi: Februari 2021

Diterima: Maret 2021

\section{Keywords:}

Learning Models, Teacher

Analysis, The Essence of

Social Studies Subjects

\begin{abstract}
Abstrak
Hasil penelitian menunjukkan bahwa (1) guru IPS di SMPN 1 Sukorejo dan SMPN 2 Sukorejo menggunakan model pembelajaran discovery learning, sedangkan guru IPS di SMPN 3 Sukorejo menggunakan model pembelajaran ceramah bervariasi, (2) guru melakukan implementasi sesuai dengan model pembelajaran yang telah dianalisis, dan dalam proses implementasi terdapat kendala yang dialami oleh guru dan peserta didik, (3) guru melakukan refleksi terhadap model pembelajaran dengan melihat keaktifan peserta didik dan hasil nilai ulangan. Lalu guru melakukan perbaikan model pembelajaran IPS dengan diskusi sesama guru, menggunakan model tutor sebaya, memanfaatkan teknologi, dan referensi buku dari berbagai sumber.
\end{abstract}

\section{Abstract}

The results showed that (1) the social studies teacher at SMPN 1 Sukorejo and $S M P N 2$ Sukorejo used the discovery learning model, while the social studies teacher at SMPN 3 Sukorejo used a varied lecture learning model, (2) the teacher implemented it according to the analyzed learning model, and in the implementation process there are obstacles experienced by teachers and students, (3) the teacher reflects on the learning model by looking at the activeness of students and the results of test scores. Then the teacher made improvements to the social studies learning model by discussing among teachers, using the peer tutor model, utilizing technology, and book references from various sources.

(C) 2021 Universitas Negeri Semarang

\footnotetext{
${ }^{\bowtie}$ Alamat korespondensi:

Gedung C1, Lantai 1, FIS UNNES

Kampus Sekaran, Gunungpati, Semarang, 50229

Email: arifpurnomo32@mail.unnes.ac.id
}

E-ISSN 2685-4929 


\section{PENDAHULUAN}

Pendidikan adalah usaha sadar dan terencana untuk mewujudkan suasana belajar dan proses pembelajaran agar peserta didik secara aktif mengembangkan potensi dirinya untuk memiliki kekuatan spiritual keagamaan, pengendalian diri, kepribadian, kecerdasan, akhlak mulia, serta keterampilan yang diperlukan dirinya, masyarakat, bangsa dan negara. Untuk mengembangkan potensi yang ada didalam diri manusia maka tidak lepas dari dunia pendidikan (UU SISDIKNAS No. 20 Tahun 2003 Bab1 Pasal 1 butir 1).

Kegiatan pembelajaran dalam kurikulum 2013 diarahkan untuk memberdayakan semua potensi yang dimiliki peserta didik agar mereka dapat memiliki kompetensi yang diharapkan melalui upaya menumbuhkan serta mengembangkan sikap, pengetahuan dan keterampilan. Di dalam kurikulum 2013peserta didik didorong untuk menemukan sendiri dan mentransformasikan informasi kompleks, mengecek informasi baru dengan yang sudah ada dalam ingatannya, melakuan pengembangan menjadi informasi atau kemampuan yang sesuai dengan lingkungan dan zaman tempat dan waktu ia hidup. Kurikulum 2013 menganut pandangan bahwa pengetahuan tidak dapat dipindahkan begitu saja dari guru ke peserta didik. Peserta didik adalah subjek yang memiliki kemampuan untuk secara aktif mencari, mengelola, mengkonstruksi, dan menggunakan pengetahuan. Untuk itu, pembelajaran harus berkenaan dengan kesempatan yang diberikan kepada peserta didik untuk mengkonstruksi pengetahuan dalam proses kognitif.

Mata pelajaran IPS di SMP/MTs menjadi acuan dalam menentukan ruang lingkup materi, proses pembelajaran, dan penilaian. Hal tersebut akan berkaitan dengan pencapaian kompetensi sikap, pengetahuan, dan keterampilan. Muatan yang yerdapat dalam pembelajaran IPS SMP/MTs berbasis pada konsep-konsep terpadu dalam berbagai disiplin ilmu. Pada hakikatnya IPS dikembangkan dalam bentuk Intergrated Social Studies. Muatan yang terkandung dalam kajian IPS antara lain, sejarah, ekonomi, sosiologi, dan geografi yang kemudian dikaitkan dengan aspek kehidupan nyata (factual/real) peserta didik sesuai dengan karakteristik tingkat perkembangannya.

Seorang guru harus memiliki kemampuan dalam mengorganisir materi pembelajaran. untuk melakukan hal tersebut, guru harus memiliki keterampilan merencanakan pembelajaran tersebut sesuai karakteristik bahan kondisi pembelajaran serta konsidi lingkungan sekolah dan masyarakat sekitarnya (Sapriya, 2009:47). Berdasarkan hal tersebut, guru dalam melakukan pembelajaran IPS terpadu dituntut untuk lebih menguasai materi IPS tidak hanya satu materi disiplin ilmu sosial tetapi guru harus mengaitkan materi ilmu sosialyaitu sejarah, ekonomi, geografi, dan sosiologi menjadi satu kesatuan sehingga batas-batas didiplin ilmu tidak nampak jelas. Hal tersebut dikarenakan konsep materi telah membaur denganpermasalahan yang ada di sekitar dan memunculkan keterpaduan dalam pembelajaran IPS.

\section{METODE}

Penelitian ini dilakukan untuk menggali informasi mengenai strategi guru dalam menerapkan model-model pembelajaran di sekolah. Fokus penelitian kemudian digunakan untuk mempermudah peneliti dalam menentukan subjek penelitian, pemilihan data, dan menjawab rumusan masalah. Fokus dalam penelitian ini lebih menitik beratkan pada kemampuan guru dalam menerapkan model pembelajaran yang tepat bagi peserta didik khususnya mata pelajaran IPS.

Subjek dalam penelitian ini terbagi menjadi dua yaitu subjek utama guru IPS yang berjumlah lima guru IPS dengan rincian SMP 1 Sukorejo, SMP 2 Sukorejo, SMP Negeri 3 Sukorejo. Selain subjek utama terdapat subjek pendukung yaitu peserta didik masing-masing empat di setiap sekolah. Penelitian ini dilakukan pada tahun ajaran2020/2021

\section{HASIL DAN PEMBAHASAN}

Penelitian ini dilakukan di SMP sekecamatan di Sukorejo yaitu SMP N 1 
Sukorejo dengan jumlah dua guru, SMP N 2 Sukorejo dengan jumlah dua guru, dan SMP 3 Sukorejo dengan jumlah 1 guru. SMP Negeri 1 Sukorejo merupakan salah satu sekolah negeri tingkat menengah yang berada di Sukorejo kabupaten Kendal. Alamat lengkap SMP Negeri 1 Sukorejo adalah J1. Lapangan Sukorejo, Sukorejo, Kec. Sukorejo, Kab. Kendal, Prov. Jawa Tengah (51363). SMP Negeri 2 Sukerojo merupakan salah satu sekolah negeri tingkat menengah yang berada di Sukorejo Kabupaten Kendal. Alamat lengkap SMP Negeri 2 Sukorejo adalah J1. Wringinsari, Kebumen, Kec. Sukorejo, Kab. Kendal, Prov. Jawa Tengah (51363). SMP Negeri 3 Sukerojo merupakan salah satu sekolah negeri tingkat menengah yang berada di Sukorejo kabupaten Kendal. Alamat lengkap SMP Negeri 3 Sukorejo adalah Jl. Jl. Resimen Kuda Putih Km.3 Harjodowo, Kec. Sukorejo, Kab. Kendal, Prov. Jawa Tengah (51363).

\section{Model Pembelajaran IPS Yang Digunakan Guru}

Hasil wawancara yang telah dilaksanakan oleh peneliti, dapat diketahui bahwa guru mata pelajaran IPS di SMP N 1 Sukorejo dan SMP N 2 Sukorejo memiliki analisis yang sama dalam menentukan model pembelajaran yang akan digunakan dalam proses pembelajaran IPS di dalam kelas. Berbeda dengan guru di SMP N 1 Sukorejo dan SMPN 2 Sukorejo, guru di SMPN 3 Sukorejo memiliki analisis yang berbeda dalam menentukan model pembelajaran. Menurut Pak Intarto selaku guru IPS di SMP N 1 Sukorejo menyatakan bahwa "saya ingin anak didik saya berfikir secara kritis tidak hanya disuapi materi saja. Saya ingin peserta didik berfikir kritis dan dapat memperoleh pengetahuan melalui dirinya sendiri mas sehingga saya lebih suka dengan model Discovery Learning".

\section{Kendala Guru Dalam Mengimplementasikan Model Pembelajaran IPS}

Setiap guru pasti memiliki hambatan ketika mengimplementasikan model pembelajaran di dalam kelas. Pertama, yaitu mengenai latar belakang pendidikan guru pada
3 SMP N di Kecamatan Sukorejo. Guru yang mengajar mata pelajaran IPS pada 3 SMP N di Kecamatan Sukorejo memiliki latar belakang pendidikan yang berbeda-beda. Guru IPS di SMP N 1 Sukorejo memiliki pendidikan yang berlatar belakang Geografi, guru di SMP N 2 Sukorejo memiliki latar belakang pendidikan Sejarah, dan guru di SMP N 3 Sukorejo memiliki latar belakang pendidikan Ekonomi. Latar belakang pendidikan guru berkaitan dengan penguasaan materi, karena basic yang guru miliki merupakan lulusan dari satu cabang ilmu pengetahuan sosial seperti contoh sejarah, sedangkan guru harus mampu mengajar materi cabang ilmu sosial lainnya seperti geografi, ekonomi, sosiologi dan lain sebagainya yang tergabung dalam satu mata pelajaran yaitu IPS terpadu.

\section{Guru Melakukan Refleksi Dan Perbaikan Terhadap Model Pembelajaran IPS}

Pembelajaran merupakan proses yang sangat kompleks. Seorang guru tidak cukup hanya memiliki bekal pengalaman saja untuk menjadi profesional dalam mengelola pembelajaran, namun guru juga harus banyak belajar mengenai bagaimana cara mengajar dan membelajarkan siswa. Salah satu cara yang dapat dilakukan oleh guru untuk meningkatkan peran dan tanggung jawab profesionalnya adalah dengan melakukan refleksi diri terutama refleksi pada model pembelajaran yang digunakan. Refleksi diri yang dilakukan oleh guru mengenai model pembelajaran bertujuan untuk mengetahui apakah materi sudah tersampaikan dengan baik atau belum. Jika dirasa materi kurang tersampaikan dengan baik oleh model pembelajaran yang digunakan, maka guru dapat melakukan pengembangan model pembelajaran selanjutnya agar materi dapat tersampaikan dengan baik.

\section{PEMBAHASAN}

\section{Model Pembelajaran IPS Yang Digunakan Guru}

Pembelajaran merupakan hubungan antara proses dan hasil. Apabila proses belajar baik, maka dapat memberikan dampak baik 
pada hasil belajar. Dalam penelitian ini aktivitas belajar sebagai prosesnya agar dapat memberi kontribusi terhadap hasil belajar IPS. Keberhasilan proses pembelajaran tidak terlepas dari peran guru untuk menentukan model-model pembelajaran yang berorientasi kepada peningkatan intensitas keterlibatan peserta didik secara efektif dalam proses pembelajaran. Penggunaan model pembelajaran yang tepat pada dasarnya bertujuan agar peserta didik dapat belajar secara aktif dan menyenangkan sehingga peserta didik dapat meraih hasil belajar yang optimal.

Penggunaan model pembelajaran sangat bermanfaat dalam pelaksanaan proses pembelajaran apabila digunakan secara tepat. Menurut Soekamto (Ramadhany, dkk 2013:36) model pembelajaran adalah kerangka konseptual yang melukiskan prosedur yang sistematis dalam mengorganisasikan pengalaman belajar untuk mencapai tujuan pembelajaran tertentu dan berfungsi sebagai pedoman bagi para perancang pembelajaran dan para pengajar dalam merencanakan aktivitas belajar mengajar.

Penelitian yang dilakukan menunjukkan bahwa guru IPS pada tiga SMPN di Kecamatan Sukorejo sudah melakukan penentuan atau pemilihan model pembelajaran sebagai pedoman guru dalam melaksanakan aktivitas pembelajaran. Selanjutnya ketiga guru IPS di SMPN Kecamatan Sukerejo memiliki tujuan dalam menentukan model pembelajaran yang akan dipilih yaitu guru ingin menjadikan peserta didik memiliki minat belajar IPS yang tinggi, aktif, dan dapat meraih hasil belajar yang optimal dengan melalui model pembelajaran yang diterapkan yaitu model pembelajaran discovery learning dan ceramah bervariasi.

Guru IPS di SMPN 1 Sukorejo dan SMPN 2 Sukorejo memilih menggunakan model pembelajaran discovery learning. Menurut Durajad dalam (Yuliana 2018:22) model discovery learning adalah teori belajar yang didefinisikan sebagai proses pembelajaran yang terjadi bila pelajar tidak disajikan dengan pelajaran bentuk finalnya, tetapi diharapkan mengorganisasi sendiri. Sedangkan menurut
Effendi dalam (Yuliana 2018:22) discovery learning merupakan suatu pembelajaran yang melibatkan peserta didik dalam pemecahan masalah untuk pengembangan pengetahuan dan keterampilan.

Sesuai dengan perkataan yang disampaikan oleh guru IPS di SMPN 1 Sukorejo dan SMPN 2 Sukorejo, keempat guru tersebut mengatakan bahwa ingin menjadikan peserta didiknya memiliki kemampuan kreatif dalam proses pembelajaran. Guru menginginkan pembelajaran dapat terjadi dua arah dan tidak bersifat teaching center. Selain itu guru IPS di SMPN 1 Sukorejo dan SMPN 2 Sukorejo mengatakan bahwa ingin peserta didiknya memiliki kemampuan dapat belajar melalui dirinya sendiri dan memiliki kemampuan dalam memecahkan masalah. Keempat guru IPS tersebut tidak ingin melihat hasil akhir pembelajarannya saja, namun yang terpenting bagi guru adalah bagaimana peserta didik melalui prosesnya dalam kegiatan pembelajaran agar peserta didik dapat mengembangkan pengetahuan dan keterampilan pada dirinya.

Sedangkan guru IPS di SMPN 3 Sukorejo memilih menggunakan model pembelajaran ceramah bervariasi. Model pembelajaran ceramah merupakan penyampaian materi secara lisan oleh guru kepada peserta didik dengan memperhatikan intonasi suara, kemampuan berbahasa dan gaya mengajar. Menurut Abdul dalam (Sari 2016:6) ceramah bervariasi merupakan salah satu upaya meningkatkan kemampuan penggunaan strategi ceramah yang mulai dikenal pada saat upaya-upaya perbaikan dalam pendidikan di sekolah.

Berdasarkan hasil penelitian, guru IPS di SMPN 3 Sukorejo masih belum bisa meninggalkan model pembelajaran yang bersifat konvensional. Guru lebih cenderung sering menggunakan model pembelajaran ceramah bervariasi yang dianggap sudah efektif. Guru mengatakan bahwa memilih model pembelajaran disesuaikan dengan karakter dan kondisi peserta didik, namun menurut guru IPS di SMPN 3 Sukorejo model pembelajaran ceramah bervariasi yang dianggap paling cocok dengan karakter dan 
kondisi peserta didik. Sehingga dalam proses pembelajaran sehari-hari guru IPS di SMPN 3 Sukorejo lebih banyak menggunakan model pembelajaran ceramah bervariasi.

Menurut Indriasih (2015:128) kurikulum

2013 merupakan salah satu perubahan paradigma pembelajaran dari pembelajaran yang bersifat konvensional menjadi yang mengaktifkan peserta didik serta melatih kemampuan berfikir kreatif peserta didik. Menurut Poerwanti (2013:49) menyatakan kurikulum 2013 memiliki tujuan membentuk perilaku peserta didik, yang digolongkan ke dalam tiga klasifikasi yaitu kognitif, afektif, psikomotor. Pembelajaran bukan hanya guru memberikan asupan materi kepada peserta didik, tetapi antara guru dan peserta didik sama-sama belajar dan saling aktif keduanya. Pendidikan yang baik menuntut adanya pembelajaran yang melatih berbagai keterampilan peserta didik. Salah satu diantaranya adalah keterampilan berfikir kreatif melalui sebuah kegiatan yang menantang. Peserta didik diharapkan mampu berfikir secara ilmiah yang salah satu diantaranya adalah berfikir kreatif. Menurut Siswono dan Novitasari dalam (Cintia, 2018:71) berfikir kreatif adalah proses berfikir yang menghasilkan berbagai macam kemungkinan jawaban. Berfikir kreatif tampak jelas dalam upaya penemuan, menuntut fleksibilitas, dan bergantung pada keberagaman sehingga berfikir kreatif menyerupai pemecahan masalah seperti usaha mencapai produksi kreatif. Melalui pembiasaan inilah, peserta didik diharapkan memiliki kemampuan untuk berfikir secara kreatif.

Berdasarkan pembahasan menunjukkan bahwa guru IPS di SMPN 1 Sukorejo dan SMPN 2 Sukorejo sudah melaksanakan atau mengimplementasikan langkah-langkah pembelajaran discovery learning yang tepat. Langkah awal guru selalu memberikan stimulus atau permasalahan kepada peserta didik. Pemberian stimulus yang dilakukan oleh guru IPS di SMPN 1 Sukorejo dan SMPN 2 Sukorejo bertujuan agar siswa mampu berfikir kreatif, dan dapat melakukan identifikasi suatu masalah. Identifikasi masalah yang dilakukan oleh peserta didik dapat menghasilkan data hipotesis atau dugaan sementara yang kemudian dikumpulkan menjadi satu untuk diolah atau dianalisis. Setelah pengolahan data, peserta didik dapat melakukan pembuktian apakah data-data yang diperoleh sesuai dengan permasalahan atau tidak. Setelah data dapat dibuktikan kebenarannya kemudian peserta didik dapat menarik kesimpulan mengenai data yang dijadikan jawaban dari suatu masalah.

Berbeda dengan guru IPS di SMPN 1 Sukorejo dan SMPN 2 Sukorejo, guru IPS di SMPN 3 Sukorejo lebih sering menggunakan model pembelajaran ceramah bervariasi. Menurut Usman (2002:34) model pembelajaran ceramah adalah 44eknik penyampaian pesan pengajaran yang sudah lazim disampaikan oleh para guru di sekolah. Pengertian senada juga diungkapkan oleh Sholahuddin, dkk (1986:43) bahwa model pembelajaran ceramah adalah suatu cara penyampaian bahan pelajaran secara lisan oleh guru di depan kelas atau kelompok. Pengertian ini memang masih memiliki kemiripan dengan definisi sebelumnya yakni menyampaikan bahan pelajaran secara lisan. Hanya saja pengertian ini lebih spesifik di mana penyampaian bahan pelajaran itu secara lisan diberikan kepada peserta didik di depan kelas. Kelas menunjukkan suatu tempat yang teratur di mana peserta didik dapat mengikuti pembelajaran dengan baik dan menyenangkan. Kelas menggambarkan strata, tingkatan, dan spesifikasi bahkan jenjang tampat yang dilalui oleh peserta didik. Kelas menjadi tempat yang harus dipersiapkan oleh guru untuk menyampaikan materi pembelajaran dengan menggunakan metode ceramah. Hal ini diperlukan karena penuturan dengan lisan dalam menyampaikan materi pembelajaran IPS menuntut suasana kondusif dan menyenangkan.

Model pembelajaran ceramah bervariasi sudah dianggap sebagai model pembelajaran yang terbaik bagi guru IPS di SMPN 3 Sukorejo untuk melakukan interaksi belajar mengajar. Namun berdasarkan hasil wawancara dengan salah satu peserta didik kelas 8 di SMPN 3 Sukorejo yang bernama Rizki mengatakan bahwa model pembelajaran 
ceramah yang dilakukan oleh guru IPS menimbulkan kebosanan pada peserta didik karena peserta didik berperan pasif dalam proses pembelajarannya. Rasa bosan yang dirasakan oleh peserta didik dalam proses pembelajaran secara tidak langsung dapat menurunkan minat dan motivasi peserta didik bahkan akhirnya dapat berdampak pada prestasi peserta didik. Hal ini juga diungkapkan oleh Tambak (2014:377) yang menyatakan bahwa satu hal yang tidak pernah menjadi refleksi bagi guru adalah tentang efektifitas penggunaan metode ceramah yaitu mengenai minat dan motivasi peserta didik dalam mengikuti pembelajaran.

\section{Kendala dalam mengimplementasikan model pembelajaran IPS}

Pelaksanaan atau mengimplementasikan model pembelajaran tidak selamanya berjalan sesuai yang diharapkan. Menurut Yusrina (2019:55) penerapan model pembelajaran inovatif dalam materi IPS selalu dihadapkan oleh berbagai macam hambatan baik itu berasal dari guru maupun peserta didik.

Berdasarkan hasil wawancara, guru dan peserta didik juga mengalami hambatan dalam proses pembelajaran. Ketiga guru IPS di SMPN Kecamatan Sukorejo juga mengalami berbagai macam hambatan pertama, latar belakang pendidikan yang dimiliki oleh guru. Ketiga guru IPS di SMPN Kecamatan Sukorejo memiliki latar belakang pendidikan yang monodisiplin seperti guru IPS di SMPN 1 Sukorejo memiliki latar belakang pendidikan geografi, guru IPS di SMPN 2 Sukorejo memiliki latar belakang pendidikan sejarah, dan guru IPS di SMPN 3 Sukorejo memiliki latar belakang pendidikan ekonomi. Dilihat dari latar belakang pendidikan yang dimiliki oleh ketiga guru di SMPN se-Kecamatan Sukorejo menunjukkan bahwa tidak ada guru yang memiliki latar belakang dari pendidikan IPS terpadu. Hal ini yang terkadang membuat kebingungan pada guru dalam menentukan model pembelajaran yang akan digunakan agar peserta didik dapat memahami, karena guru yang memiliki latar belakang pendidikan monodisiplin juga harus mampu dan siap mengajar materi dari disiplin ilmua lainya.
Seperti guru dengan latar belakang pendidikan geografi harus siap dan mampu mengajar sejarah, ekonomi, sosiologi, dan lain-lain yang berbeda dengan latar belakang pendidikannya. Dalam menentukkan dan mengimplementasikan model pembelajaran yang tentunya guru harus benar-benar mencari tahu model pembelajaran apa yang sekiranya cocok dengan materi yang akan disampaikan.

Kedua, selain itu guru mengalami hambatan dalam menerapkan model pembelajaran dikarenakan guru belum mendapatkan pelatihan secara intensif terkait model pembelajaran yang sesuai dengan kurikulum 2013. Sedangkan tidak semua guru memiliki kemampuan yang sama dalam menentukan model pembelajaran yang inovatif bahkan terkait dengan usia para guru itu sendiri yang membuat guru mengalami kendala dalam menentukan model pembelajaran yang sesuai dengan kurikulum yang ditetapkan dan harus dilaksanakan.

Ketiga, hambatan selanjutnya yang dialami guru yaitu terkait dengan waktu. Menurut ketiga guru IPS di SMPN Kecamatan Sukorejo model pembelajaran inovatif adalah model pembelajaran yang menggunakan berbagai macam media atau alat peraga. Pembuatan media atau alat peraga menjadi kendala karena keterbatasan waktu. Guru tidak memiliki waktu lebih untuk membuat media atau alat peraga karena menurutnya ketika di sekolah guru bertugas mengajar dan ketika di rumah guru bertugas mengurus kebutuhan rumah tangganya. Sehingga ketiga guru IPS di SMPN Kecamatan Sukorejo lebih memanfaatkan fasilitas yang tersedia di sekolahan dan memanfaatkan teknologi yaitu mencari video-video pembelajaran yang ada di internet.

Keempat, hambatan terakhir ada pada kondisi peserta didik. Guru sangat mengharapkan semua peserta didik dapat berperan aktif di dalam proses pembelajaran, tetapi kenyataannya peserta didik masih ada yang bersifat pasif entah karena malu untuk mengungkapkan pendapatnya atau tidak paham dengan materi yang diajarkan. Hal ini senada dengan pernyataan Trianto (2007:1) yaitu masalah yang muncul dalam proses 
pembelajaran pada pendidikan formal (sekolah) dewasa ini adalah masih rendahnya daya serap peserta didik. Guru selalu berusaha memberikan stimulus bagi peserta didiknya agar dapat memancing peserta didik menjadi aktif, tetapi walaupun guru sudah memberikan stimulus masih ada sebagian kecil dari peserta didik yang masih terlihat pasif. Suasana kelas juga terkadang gaduh sehingga guru harus memiliki tingkat kesabaran yang tinggi dan guru harus terus belajar mengkondisikan kelas agar pembelajaran berjalan secara kondusif.

\section{Guru Melakukan Refleksi dan Pengembangan Model Pembelajaran IPS}

Yulianto, dkk (2018:30) profesionalisme guru sangat penting dalam menunjang proses pembelajaran di kelas. Indonesia adalah negara yang memiliki kualitas pendidikan belum baik. Salah satu faktor yang mempengaruhinya adalah sumber daya manusia yaitu guru. seorang pendidik dituntut memiliki tiga kompetensi wajib yaitu pedagogik, sosial, dan professional. Kompetensi pedagogik menjadi kebutuhan yang mutlak bagi seorang guru. Menjadi seorang guru yang mampu mengajar di kelas dengan baik membutuhkan pengalaman yang cukup banyak dan waktu yang lama. Namun jika harus demikian maka kebutuhan guru di lapangan akan sulit terpenuhi. Ada salah satu cara yang mampu untuk menginkatkan kapasitas guru dalam mengajar yaitu kemampuan refleksi seorang guru. Menurut Fatemipour dalam (Yulianto, dkk, 2018:31) refleksi adalah prosedur baik yang dapat digunakan para guru untuk menyelidiki dan menjadikan praktik mengajar guru agar lebih baik.

Ada banyak cara guru dalam melakukan refleksi dalam pembelajaran terutama refleksi pada model pembelajaran yang digunakan. Refleksi pada model pembelajaran juga sangat penting dilakukan agar mendapatkan hasil belajar yang maksimal pada peserta didik. Kelima guru di SMPN Kecamatan Sukorejo melakukan refleksi pada model pembelajaran secara sederhana seperti yang diungkapkan oleh Pak Intarto. Pak Intarto dalam melakukan refleksi terhadap tepat atau tidaknya model pembelajaran yang digunakan yaitu dengan melihat kondisi peserta didik. Berdasarkan penuturan Pak Intarto peserta didik pernah mengungkapkan keluhannya kepada Pak Intarto. Peserta didik mengeluh karena model pembelajaran yang digunakan pada tiap pertemuan bersifat monoton. Dengan keluhan yang diungkapkan oleh peserta didik membuat Pak Intarto refleksi diri untuk melakukan perbaikan terhadap model pembelajaran yang akan diterapkan selanjutnya. Hal itu juga diungkapkan Bu Pur selaku guru IPS di SMP $\mathrm{N} 1$ Sukorejo dengan keluhan peserta didik tentang model pembelajaran yang digunakan tiap pertemuan masih sama dan bersifat monoton.

Refleksi diri juga dilakukan oleh Pak Dwi dan Pak Cahyo secara sederhana dengan melihat keaktifan peserta didik di dalam kelas. Refleksi yang dilakukan oleh Pak Dwi yaitu dengan cara setiap pertemuan belajar Pak Dwi sering memberikan beberapa pertanyaan kepada peserta didik. Jika mayoritas peserta didik dapat menjawab pertanyaan maka Pak Dwi beranggapan bahwa peserta didik sudah dapat menerima materi yang diajarkan melalui model pembelajaran yang diterapkan. Namun jika mayoritas peserta didik tidak dapat menjawab pertanyaan-pertanyaan terkait materi maka Pak Dwi beranggapan peserta didik belum mampu menerima materi dengan baik dan Pak Dwi segera memikirkan ulang mengenai metode apa yang tepat digunakan agar peserta didik dapat menerima materi dengan baik.

Bu Salimah juga mengungkapkan hal yang serupa dengan Pak Dwi mengenai refleksi diri yaitu dengan cara melihat kemampuan peserta didiknya. Bu Salimah mengatakan bahwa berhasil tidaknya materi tersampaikan dapat dilihat melalui hasil tugas harian atau nilai ulangan. Jika nilainya baik, Bu Salimah memiliki anggapam bahwa peserta didik dapat menerima materi yang disampaikan. Namun sebaliknya, jika nilai peserta didik maka Bu Salimah beranggapan bahwa peserta didik belum dapat menerima materi dengan baik.

Pernyataan yang dikemukakan oleh ketiga guru IPS di SMPN Kecamatan Sukorejo sesuai dengan pendapat Korthagen dan Vasalos (2005:47) yaitu salah satu aspek yang 
merupakan fokus refleksi guru dalam praktek profesionalnya adalah dengan melihat respon terhadap pentingnya meningkatkan kompetensi profesionalnya.

\section{Guru melakukan pengembangan model pembelajaran IPS}

Dewasa ini proses belajar dalam pembelajaran yang modern terkadang mengalami hambatan pada psikologis peserta didik yang dinilai belum siap untuk mengkonstruksikan pola pikirnya. Penerapan model pembelajaran yang monoton, proses belajar yang terlalu serius dan membosankan menyebabkan terhambatnya proses pola pikir pada peserta didik. Proses belajar dengan struktur yang berlebihan juga berdampak pada rendahnya motivasi, minat belajar, dan hasil belajar. Dengan demikian guru harus mampu melakukan terobosan baru yaitu dengan meningkatkan atau mengembangkan model pembelajaran yang lebih relevan (Jayawardana dan Djukri, 2015:168).

Hal ini sesuai dengan pendapat ketiga guru IPS di SMPN Kecamatan Sukorejo. Ketiga guru IPS beranggapan bahwa selalu ada peserta didik yang mengalami kebingungan atau tidak paham dengan materi yang diajarkan oleh guru tetapi malu untuk bertanya kepada guru. Dengan adanya tutor sebaya di mana peserta didik yang dianggap lebih mampu memahami materi akan menyampaikan materi IPS kepada peserta didik yang belum paham. Penyampaian materi yang dilakukan antar peserta didik membuat peserta didik yang tidak paham menjadi leluasa untuk bertanya kepada temannya tanpa rasa malu. Hal ini juga disampaikan oleh Pak Intarto. Pak Dwi pun mengungkapkan bahwa tugas dari tutor sebaya adalah membantu guru dalam menyampaikan materi kepada peserta didik yang belum paham terkait materi yang diajarkan.

Di dalam tutor sebaya guru hanya memberikan konsep. Pengembangan dari konsep tersebut kemudian selanjutnya dilakukan oleh peserta didik dalam bentuk kelompok kecil. Dalam kelompok kecil tersebut kemudian mendiskusikan konsep jawaban dari soal-soal yang diberikan, memahami konsep pengerjaan secara bersamasama sehingga peserta didik terlibat langsung dalam penguasaan materi IPS. Menurut Masitoh (2009:233) dalam proses pembelajaran guru bukan satu-satunya narasumber dalam penyampaian materi tetapi berperan juga sebagai mediator, stabilisator, dan manajer pembelajaran.

Selain menggunakan tutor sebaya, ketiga guru IPS di SMPN Kecamatan Sukorejo juga memanfaatkan teknologi untuk mencari model pembelajaran beserta langkah-langkahnya dalam mengimplementasikannya. Selain itu Pak Intarto dan Pak Dwi mengarahkan peserta didik agar tidak hanya menggunakan referensi buku saja tetapi Pak Intarto dan Pak Dwi mengarahkan peserta didik untuk memanfaatkan teknologi seperti mencari video atau materi pembelajaran melalui internet. Sedangkan Bu Salimah tetap menggunakan buku sebagai referensi peserta didik untuk belajar entah buku LKS maupun buku cetak di perpustakaan yang telah tersedia di sekolah.

\section{Guru meningkatkan minat pembelajaran IPS pada peserta didik}

Minat belajar besar pengaruhnya terhadap hasil belajar, karena jika bahan pelajaran tidak sesuai dengan minat peserta didik maka peserta didik tidak akan belajar dengan baik karena tidak ada daya tarik baginya. Belajar timbul dengan adanya minat yang timbul dari dalam diri peserta didik dan dapat juga timbul karena pengaruh orang lain seperti orang tua dan guru. Sehubungan dengan minat, Slameto (2003:188) menyatakan minat adalah suatu rasa lebih suka dan rasa ketertarikan pada suatu hal atau aktivitas, tanpa ada yang menyuruh. Sedangkan menurut Sadirman (2009:112) menyatakan minat belajar yang ada pada diri peserta didik adalah tekun dalam menghadapi tugas belajar, tidak mudah putus asa, tidak cepat puas terhadap hasil belajar yang diperoleh, tidak tergantung pada orang lain, tidak cepat bosan dan tekun mengerjakan tugas yang diberikan. Berdasarkan pendapat para ahli yang telah dipaparkan sebelumnya dapat disimpulkan bahwa pengertian minat belajar yaitu sesuatu yang tersembunyi pada diri peserta didik yang mendorongnya untuk 
melakukan sesuatu dalam bentuk kegiatan belajar atau bekerja dengan ciri-ciri tekun, ulet, tidak mudah putus asa, tidak cepat puas, dan tidak bergantung pada orang lain.

Kelima guru IPS pada SMPN di Kecamatan Sukorejo sama-sama menerapkan ice breaking dalam prose pembelajaran. Strategi yang digunakan oleh para guru dalam melaksanakan ice breaking berbeda-beda. Pak Intarto guru IPS di SMPN 1 Sukorejo menerapkan ice breaking pada saat pertengahan proses pembelajaran dengan cara melihat kondisi peserta didik. Jika peserta didik dirasa sudah terlihat lelah, bosan, atau tegang biasanya Pak Intarto melakukan ice breaking dengan cara menampilkan video-video lucu yang diambil dari Youtube agar suasana pembelajaran menjadi kondusif kembali.

Selain pemberian ice breaking, pemberian reward dan punishment juga menjadi cara guru dalam meningkatkan minat belajar IPS. Menurut Melinda dan Ratnawati (2018:83) pembelajaran IPS akan lebih menarik ketika guru menghadirkan suatu apresiasi dengan cara memberikan reward dan punishment pada saat pembelajaran. Pada dasarnya pemberian reward dan punishment pada peserta didik dapat mempermudah guru untuk meningkatkan minat belajar peserta didik agar mencapai suatu tujuan dari pembelajaran. Pemberian reward dan punishment sangat penting dalam memotivasi peserta didik untuk meningkatkan minat belajar IPS, karena melalui reward dan punishment peserta didik akan lebih percaya diridan bertanggung jawab dengan tugas yang diberikan. Reward dan punishment dua kata yang saling bertolak belakang akan tetapi keduanya saling berkaitan dalam memicu peserta didik dalam meningkatlan minat belajar IPS.

Berdasarkan pemaparan di atas, meningkatkan minat belajar IPS pada peserta didik sangat perlu dilakukan. Guru memiliki berbagai macam cara dalam meningkatkan minat belajar peserta didik. Namun pada guru IPS di SMPN Kecamatan Sukorejo ketiga guru memiliki strategi yang sama dalam meningkatkan minat belajar yaitu dengan memberikan ice breaking dan pemberian reward dan punishment pada peserta didik.

\section{SIMPULAN}

Guru IPS di SMPN 1 Sukorejo dan di SMPN 2 Sukorejo sama-sama menggunakan model pembelajaran discovery learning yang dianggap dapat membuat peserta didik mampu berfikir kreatif. Sedangkan guru IPS di SMPN 3 Sukorejo masih menggunakan model pembelajaran ceramah bervariasi. Kendala yang dialami guru yaitu latar belakang pendidikan guru, di mana tidak ada guru IPS di SMPN se-kecamatan Sukorejo yang memiliki latar belakang pendidikan IPS terpadu, guru belum mendapatkan pelatihan secara intensif terkait pembelajaran kurikulum 2013, keterbatasan waktu dalam membuat model pembelajaran yang bervariatif, dan kondisi peserta didik yang terkadang sulit dikondisikan. Guru IPS di 3 SMPN sekecamatan Sukorejo melakukan refleksi terkait model pembelajaran dengan melihat kemampuan peserta didik berdasarkan keaktifan di dalam kelas dan hasil nilai ulangan.

\section{DAFTAR PUSTAKA}

Cintia, Nichen Irma, dkk. 2018. "Penerapan Model Pembelajaran Discovery Learning untuk Meningkatkan Kemampuan Berfikir Kretaif dan Hasil Belajar Siswa". Jurnal Ilmu Pendidikan. Vol. 32. No 1

Indriasih, A. 2015. "Pemanfaatan Alat Permainan Edukasi Ular Tangga dalam Penerapan Pembelajaran Tematik di Kelas III SD". Jurnal Pendidikan. Vol. 16. No. 6

Melinda, Ima dan Ratnawati Susanto. 2018. "Pengaruh Reward dan Punishment terhadap Motivasi Belajar Siswa". Jurnal Pendidikan Dasar. Vol. 2. No. 2. E-ISSN 2549-6050

Sholahuddin, Mahfuz. 1986. Metodologi Pendidikan Islam. Surabaya: PT Bina Ilmu

Ramadhany, Tazkia, dkk. 2015. "Analisis Model dan Media Pembelajaran yang Digunakan oleh Guru pada Mata Pelajaran Ekonomi di SMA Se- 
Kecamatan Inderalaya". Jurnal Pendidikan Ekonomi. Vol. 2. No. 1. Hal 36

Supriya, 2009. Pendidikan IPS Konsep dan Pembelajaran. Bandung: PT. Remaja Rosdakarya.

Yuliana, Nabila. 2018. "Penggunaan Model Pembelajaran Discovery Learning dalam Peningkatan Hasil Belajar Siswa di Sekolah Dasar". Jurnal Ilmiah Pendidikan dan Pembelajaran. Vol. 2. No. 1. E-ISSN:2615-6091. Hal 22
Yulianto, Eko, dkk. 2018. "Analisis Refleksi pada Pembelajaran: Review Reasearch". Artikel. ISBN: 978-6025614-35-4

Yusrina, Farida, dkk. 2019. "Hambatan Guru dalam Menerapkan Model Pembelajaran Inivatif pada Mata Pelajaran Sejarah di SMP Negeri 3 Magelang". Jurnal Penelitian dan Inovasi Pendidikan Sejarah. Vol. 8 No. 1. E-ISSN 2684-9771 